\title{
Histological Adaptations of the Gastrointestinal Tract of Broilers Fed Diets Containing Insoluble Fiber from Rice Hull Meal
}

\author{
Tossaporn Incharoen
}

\author{
Department of Agricultural Science, \\ Faculty of Agriculture Natural Resources and Environment, \\ Naresuan Univeristy, Phitsanulok 65000, Thailand
}

Received 2013-05-29, Revised 2013-06-18; Accepted 2013-06-20

\begin{abstract}
These two experiments were aimed to determine the effects of diets containing high levels of insoluble fiber from Rice Hull Meal (RHM) on performance and intestinal histological variables of broilers. In the first experiment, 150 10-day-old Hubbard male broiler chicks were randomly allocatted to three treatments and fed diets containing RHM at 0,50 and $100 \mathrm{~g} \mathrm{~kg}^{-1}$ until 42 days old. Body weight gain was significantly higher $(\mathrm{p}<0.05)$ in the $100 \mathrm{~g} \mathrm{~kg}^{-1}$ RHM group than the control birds, resulting in a decreasing feed conversion ratio. In the second experiment, 64 14-day-old birds were assigned into 4 groups and fed diets containing RHM at $0,100,200$ or $300 \mathrm{~g} \mathrm{~kg}^{-1}$. Tissue sampling procedures of each group were conducted at 42 days old. There were no considerable differences in carcass characteristics, intestinal weight and length, villus area, crypt depth or mucosa thickness. Increases $(\mathrm{p}<0.05)$ in intestinal diameter, gizzard weight and muscular is externa thickness were observed in the dietary RHM groups. In contrast, the villus height and the digesta $\mathrm{pH}$ of the crop and gizzard tended to decrease with increasing levels of dietary RHM and significantly declined $(\mathrm{p}<0.05)$ in the 200 and $300 \mathrm{~g} \mathrm{~kg}^{-1}$ groups. Epithelial cells seem to demonstrate similar histological changes. Nonetheless, segmented filamentous bacteria adhered to the ileal epithelial cells in the dietary RHM groups. In conclusion, the present findings suggest that RHM can be used as a source of insoluble fiber in broiler diets at $100 \mathrm{~g} \mathrm{~kg}^{-1}$ to improve performance without any adverse effects on carcass characteristics, gastrointestinal tract and histological variables of the intestinal villi and epithelial cells.
\end{abstract}

Keywords: Broilers, Histological Adaptations, Insoluble Fiber, Rice Hull, Small Intestine

\section{INTRODUCTION}

Antibiotics have been widely used in chicken production to control animal pathogens and diseases and to improve broiler performance (Miles et al., 2006). However, continued use of antibiotics has induced the development of antibiotic-resistant pathogenic bacteria and changes in the microflora of the gastrointestinal tract. By extension, antibiotic residues in animal products have been recognized as a threat to consumer health. As result of such concerns, many countries around the world are pushing forward to place bans on the use of antibiotics in chicken production. Consequently, chicken producers must develop alternatives to antibiotics to enhance physiological functions and growth rates, through the use of natural products that do not compromise productivity. Current antibiotic replacement strategies have involved the use of probiotics, prebiotics or synbiotics to improve the gut environment in non-ruminants. But these supplements are expensive, which directly affects the production costs of local animal producers.

Recently, animal research evidence is indicating that insoluble fiber is advantageous to gastrointestinal 
development (Hetland and Svihus, 2001; 2007; GonzalezAlvarado et al., 2007; Jimenez-Moreno et al., 2009) and stimulates the production of hydrochloric acid, bile acids and digestive enzyme secretion (Hetland et al., 2003; Svihus, 2011). Moreover, the optimal inclusion of insoluble fiber in broiler diets could improve crude fat and starch digestibility (Hetland et al., 2003) and extend nutrient retention (Jimenez-Moreno et al., 2009). In Thailand, the rice hull is one of the by-products of rice processing in rice mills. The major chemical component of the rice hull is insoluble fiber.

In the current research, rice hulls, the by-product of rice mills, are used as a source of insoluble fiber. To produce Rice Hull Meal (RHM), rice hulls are ground in a rotary mill and passed through a $1-\mathrm{mm}$ screen. The main components of RHM are cellulose (about 38\%), hemicelluloses (about 20\%) and lignin (about 22\%). Even though the effects of insoluble dietary fiber on poultry productivity, physiology of digestive system and the morphological change of the gastrointestinal tract have been widely determined, the use of RHM as insoluble fiber in broiler production has not reported. The author therefore assessed the effect of diets containing high levels of insoluble fiber from RHM on broiler performance in experiment 1. Carcass characteristics, digesta $\mathrm{pH}$ and intestinal histological parameters (light and scanning electron microscopic techniques) were investigated in experiment 2.

\section{MATERIALS AND METHODS}

\subsection{Experiment Design}

In experiment 1, a total of 150 day-old Hubbard male broiler chicks were obtained from a local company (Muangpol Farm Co., Ltd., Phitsanulok, Thailand) and used in this study. The chicks were placed into a brooding area and provided ad libitum access to water and a commercial diet. A 2-phase feeding program was applied, with a starter diet provided until 21 days of age and a grower diet until 42 days of age. At 10 days old, 150 birds were randomly allocatted to 3 dietary treatments, each with 5 replicates of 10 birds. Chickens were fed the basal diets (Table 1) containing RHM at 0 (control group), 50 and $100 \mathrm{~g} \mathrm{~kg}^{-1}$. Body weight and feed intake were recorded until 42 days of age and feed efficiency was calculated.

In experiment 2, 64 uniform weight birds (14 days old) were assigned into 4 groups, each with 4 replicates of 4 chicks. All experimental birds were reared in wire cages in a temperature-controlled room with a 14-h photo-period. One group was fed a basal diet (Table 1) with no inclusion of RHM (control group), while the three remaining groups were fed the basal diet augmented with RHM at 100, 200 or $300 \mathrm{~g} \mathrm{~kg}^{-1}$ respectively. At the end of the feeding period, one bird from each replicate was euthanized to measure carcass characteristics, the $\mathrm{pH}$ of intestinal contents, the gross anatomy of the gastrointestinal tract and intestinal histology. Management and sampling procedures of all birds were conducted as follows.

\subsection{Carcass Characteristics and Intestinal Gross Anatomical Measurements}

At the end of the feeding trial, 4 birds per group were weighed and euthanized without previous feed deprivation. After removal of the feathers, the carcasses were left for one hour to remove excess water and then weighed. The dressed weights were recorded before eviscerating the breast, wing and thigh plus drumstick. The visceral organs (heart, liver, proventriculus and gizzard) were carefully dissected, removed and then weighed. For the gross measurement of the intestine, the whole small intestine was dissected and the empty weight of the duodenum (duodenal loop), jejunum (end of the duodenum to Meckel's diverticulum) and ileum (Meckel's diverticulum to the ileo-cecal junction) were measured. The length and weight were measured in each intestinal segment. All dissections and processing were done on the same day and by the same person to ensure uniformity. The measurements were calculated as percentages of the body weight.

\subsection{Tissue Collection and Microscopic Assessment}

Four birds with body weights close to the average were chosen from each group. They were euthanized under anaesthesia with diethyl ether to obtain tissues for microscopic assessment. Segments of the intestine were collected from the midpoints of the duodenum, jejunum and ileum.

For light microscopy, each intestinal segment (approximately $2-3 \mathrm{~cm}$ in length) was gently flushed with Phosphate Buffered Saline (PBS) to remove the intestinal contents and placed in Bouin's solution until further processing. 
Table 1. Feed formulation and nutrient composition of the basal diets

\begin{tabular}{|c|c|c|c|c|}
\hline \multirow[b]{2}{*}{ Items } & \multicolumn{2}{|c|}{ Experiment 1} & \multicolumn{2}{|c|}{ Experiment 2} \\
\hline & Starter & Grower & Starter & Grower \\
\hline \multicolumn{5}{|l|}{ Ingredients } \\
\hline Corn meal & 43.00 & 52.70 & 51.0 & 58.00 \\
\hline Rice bran & 9.00 & 11.00 & - & - \\
\hline Milo & - & - & 2.00 & 9.00 \\
\hline Soybean meal & 43.00 & 31.00 & 37.45 & 23.20 \\
\hline Fish meal & - & - & 4.00 & 4.00 \\
\hline Vegetable fat (palm oil) & 1.00 & 1.50 & 1.50 & 2.00 \\
\hline DL-Methionine & 0.20 & 0.10 & 0.20 & 0.1 \\
\hline Dicalcium phosphate & 2.00 & 2.00 & 2.00 & 2.00 \\
\hline Calcium carbonate & 0.95 & 1.00 & 1.00 & 1.00 \\
\hline Sodium chloride & 0.35 & 0.35 & 0.35 & 0.35 \\
\hline Premix $^{1}$ & 0.50 & 0.35 & 0.50 & 0.35 \\
\hline Chemical composition & - & - & - & - \\
\hline Crude protein, $\%$ & 22.00 & 18.00 & 22.00 & 18.00 \\
\hline Ether extract, \% & 4.10 & 5.90 & 4.00 & 6.00 \\
\hline Crude fiber, $\%$ & 4.00 & 4.10 & 4.00 & 4.00 \\
\hline Crude ash, $\%$ & 6.90 & 6.70 & 7.00 & 7.00 \\
\hline Calcium, $\%$ & 0.75 & 0.70 & 0.80 & 0.70 \\
\hline Available phosphorus, \% & 0.40 & 0.35 & 0.37 & 0.28 \\
\hline $\mathrm{ME}, \mathrm{kcal} / \mathrm{kg}$ & $3,000.00$ & $3,200.00$ & $3,050.00$ & $3,250.00$ \\
\hline
\end{tabular}

${ }^{\mathrm{T}}$ Supplied per $100 \mathrm{~kg}$ of diet : vitamin A, 15,000,000 IU; vitamin D, 3,000,000 IU; vitamin E, 26,000 IU; vitamin K, 35 g; vitamin B1, $2.5 \mathrm{~g}$; vitamin B2, $6.5 \mathrm{~g}$; vitamin B6, $257.5 \mathrm{~g}$; vitamin B12, $26 \mathrm{mg}$; pantothenic acid, $11.04 \mathrm{~g}$; nicotinic acid, $35 \mathrm{~g}$; folic acid, $1.2 \mathrm{~g}$; biotin, $15.1 \mathrm{mg}$; choline chloride, $250 \mathrm{~g}$; copper, $1.6 \mathrm{~g}$; manganese, $60.2 \mathrm{~g}$; iron, $1.6 \mathrm{~g}$; zinc, $45 \mathrm{~g}$; iodine, $400 \mathrm{mg}$; and selenium, $160 \mathrm{mg}$.

The fixed intestinal segment was cut into $1-\mathrm{cm}$ sections, dehydrated through a graded series of ethanol and embedded in paraffin. Embedded samples were transversely cut at $4 \mu \mathrm{m}$, mounted onto glass slides and observed under light microscope. Histological parameters (villus height, villus area, crypt depth, muscularis externa thickness and mucosa thickness) were assessed employing procedures used previously (Incharoen et al., 2010).

For scanning electron microscopy, after tissues were opened along the mesenteric side, they were washed with a jet dropper of 0.1M PBS ( $\mathrm{pH} 7.4$ ), pinned flat on paraffin plates and instantly placed into a fixative solution (4\% paraformaldehyde and 3\% glutaraldehyde buffered with $0.1 \mathrm{M}$ cacodylate, $\mathrm{pH} 7.4$ ). The flattened sample was cut into small pieces with a razor blade, rinsed several times with $0.1 \mathrm{M}$ cacodylate buffer $(\mathrm{pH}$ 7.4) and dehydrated in a graded series of ethanol. These specimens were freeze-dried, mounted on aluminum stubs, coated with platinum and examined using a scanning electron microscope (Incharoen et al., 2010).

\subsection{Statistical Analyses}

Data collected for growth performance, carcass yield, intestinal weight and length, digesta $\mathrm{pH}$ and light microscopic parameters were statistically examined by using one-way analysis of variance (ANOVA) in the
SPSS statistical software package. Duncan's multiple range test was applied to compare the significance of differences between the means. Results $\mathrm{p}<0.05$ were considered statistically significant.

\section{RESULTS}

\subsection{Experiment 1}

\subsubsection{Growth Performance}

The feed intake, body weight gain and Feed Conversion Ratio (FCR) are presented in Table 2. Feed intake did not differ significantly $(\mathrm{p}>0.05)$ among the experimental groups. Compared with control birds, the $100 \mathrm{~g} \mathrm{~kg}^{-1}$ RHM-fed birds showed a significantly higher $(\mathrm{p}<0.05)$ body weight gain $(2120.42 \mathrm{Vs} 1984.73 \mathrm{~g}$ bird $\left.^{-1}\right)$, resulting in a significantly decreased $(p<0.05)$ feed conversion ratio (2.02 Vs $\left.2.14 \mathrm{bird}^{-1}\right)$.

\subsection{Experiment 2}

\subsubsection{Carcass Characteristics, Digesta $\mathrm{pH}$ and Gross Anatomy of the Gastrointestinal Tract}

Table 3 describes the carcass characteristics and $\mathrm{pH}$ digesta in the crop, gizzard and small intestine of broiler chickens. 
Table 2. The effect of dietary RHM on growth performance of broiler chickens (mean $\pm \mathrm{SE}$ )

\begin{tabular}{|c|c|c|c|}
\hline \multirow[b]{2}{*}{ Items } & \multicolumn{3}{|c|}{ Dietary RHM (g/kg) } \\
\hline & 0 & 50 & 100 \\
\hline$\overline{\text { Body weight gain (g/bird) }}$ & $1984.73 \pm 20.21^{\mathrm{b}}$ & $2009.53 \pm 19.81^{\mathrm{b}}$ & $2120.42 \pm 43.56^{\mathrm{a}}$ \\
\hline Feed intake (g/bird) & $4252.40 \pm 23.48$ & $4262.60 \pm 39.70$ & $4269.00 \pm 15.31$ \\
\hline Feed conversion ratio (FCR) & $2.14 \pm 0.02^{\mathrm{b}}$ & $2.12 \pm 0.01^{\mathrm{b}}$ & $2.02 \pm 0.03^{\mathrm{a}}$ \\
\hline
\end{tabular}

${ }^{\mathrm{ab}}$ Means within each grouping with different letter designations differ $(\mathrm{p}<0.05)$

Table 3. The effect of dietary RHM on carcass characteristics and pH digesta in the crop, gizzard and small intestine of chickens (mean $\pm \mathrm{SE})$

\begin{tabular}{|c|c|c|c|c|}
\hline \multirow[b]{2}{*}{ Items } & \multicolumn{3}{|c|}{ Dietary RHM (g/kg) } & \multirow[b]{2}{*}{300} \\
\hline & 0 & 100 & 200 & \\
\hline \multicolumn{5}{|l|}{ Carcass yield (\%) } \\
\hline Dressing & $78.58 \pm 1.08$ & $79.06 \pm 0.41$ & $78.16 \pm 0.34$ & $78.26 \pm 0.59$ \\
\hline Breast & $12.91 \pm 0.44^{\mathrm{a}}$ & $12.19 \pm 0.53^{\mathrm{ab}}$ & $11.20 \pm 0.41^{\mathrm{bc}}$ & $10.83 \pm 0.48^{\mathrm{c}}$ \\
\hline Wings & $9.44 \pm 0.27$ & $9.70 \pm 0.18$ & $9.35 \pm 0.20$ & $9.40 \pm 0.41$ \\
\hline Thighs +drumsticks & $19.93 \pm 0.56$ & $21.16 \pm 1.39$ & $21.11 \pm 1.00$ & $21.93 \pm 0.42$ \\
\hline Heart & $0.75 \pm 0.03$ & $0.74 \pm 0.06$ & $0.69 \pm 0.04$ & $0.74 \pm 0.04$ \\
\hline Liver & $2.32 \pm 0.06$ & $2.50 \pm 0.16$ & $2.67 \pm 0.07$ & $2.65 \pm 0.10$ \\
\hline Proventriculus & $0.43 \pm 0.01$ & $0.43 \pm 0.05$ & $0.41 \pm 0.05$ & $0.41 \pm 0.03$ \\
\hline Gizzard & $2.09 \pm 0.16^{\mathrm{b}}$ & $2.04 \pm 0.07^{\mathrm{b}}$ & $2.58 \pm 0.15^{\mathrm{a}}$ & $2.81 \pm 0.18^{\mathrm{a}}$ \\
\hline \multicolumn{5}{|l|}{ Digesta $\mathrm{pH}$} \\
\hline Crop & $5.30 \pm 0.10^{\mathrm{a}}$ & $5.49 \pm 0.16^{\mathrm{a}}$ & $4.94 \pm 0.03^{\mathrm{b}}$ & $5.01 \pm 0.04^{\mathrm{b}}$ \\
\hline Gizzard & $4.02 \pm 0.18^{\mathrm{a}}$ & $4.06 \pm 0.08^{\mathrm{a}}$ & $3.19 \pm 0.12^{\mathrm{b}}$ & $3.36 \pm 0.12^{\mathrm{b}}$ \\
\hline Duodenum & $5.83 \pm 0.03$ & $5.93 \pm 0.05$ & $5.86 \pm 0.02$ & $5.89 \pm 0.02$ \\
\hline Jejunum & $6.21 \pm 0.06$ & $6.43 \pm 0.12$ & $6.25 \pm 0.11$ & $6.14 \pm 0.05$ \\
\hline Ileum & $7.56 \pm 0.07$ & $7.66 \pm 0.12$ & $7.64 \pm 0.07$ & $7.46 \pm 0.03$ \\
\hline
\end{tabular}

${ }^{\mathrm{ab}}$ Means within each grouping with different letter designations differ $(\mathrm{p}<0.05)$

Table 4. The effect of dietary RHM on gross intestinal morphology of chickens (mean $\pm \mathrm{SE}$ )

\begin{tabular}{|c|c|c|c|c|}
\hline \multirow[b]{2}{*}{ Items } & \multicolumn{3}{|c|}{ Dietary RHM (g/kg) } & \multirow[b]{2}{*}{300} \\
\hline & 0 & 100 & 200 & \\
\hline \multicolumn{5}{|c|}{ Intestinal weight (\%)* } \\
\hline Duodenum & $0.57 \pm 0.04$ & $0.67 \pm 0.03$ & $0.65 \pm 0.02$ & $0.69 \pm 0.03$ \\
\hline Jejunum & $0.94 \pm 0.05$ & $1.06 \pm 0.06$ & $1.08 \pm 0.03$ & $0.97 \pm 0.03$ \\
\hline Ileum & $0.89 \pm 0.08$ & $0.84 \pm 0.07$ & $0.84 \pm 0.03$ & $0.86 \pm 0.04$ \\
\hline Ceca (pair) & $0.46 \pm 0.02$ & $0.49 \pm 0.02$ & $0.46 \pm 0.02$ & $0.47 \pm 0.04$ \\
\hline \multicolumn{5}{|c|}{ Intestinal length (cm $\left.100 \mathrm{~g}^{-1} \mathrm{BW}\right)$} \\
\hline Duodenum & $1.81 \pm 0.07$ & $1.94 \pm 0.13$ & $1.95 \pm 0.12$ & $1.99 \pm 0.11$ \\
\hline Jejunum & $3.79 \pm 0.42$ & $4.02 \pm 0.18$ & $4.07 \pm 0.23$ & $4.12 \pm 0.21$ \\
\hline Ileum & $4.03 \pm 0.23$ & $4.19 \pm 0.18$ & $4.22 \pm 0.31$ & $4.18 \pm 0.17$ \\
\hline Ceca** & $1.07 \pm 0.05$ & $1.01 \pm 0.08$ & $1.11 \pm 0.10$ & $1.23 \pm 0.08$ \\
\hline \multicolumn{5}{|c|}{ 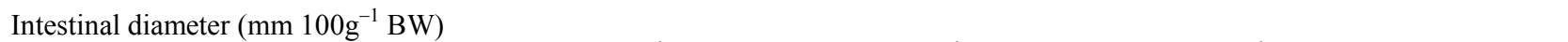 } \\
\hline Duodenum & $0.60 \pm 0.01^{\mathrm{b}}$ & $0.60 \pm 0.02^{\mathrm{b}}$ & $0.62 \pm 0.04^{\mathrm{b}}$ & $0.70 \pm 0.01^{\mathrm{a}}$ \\
\hline Jejunum & $0.57 \pm 0.02^{\mathrm{b}}$ & $0.56 \pm 0.03^{b}$ & $0.60 \pm 0.01^{\mathrm{ab}}$ & $0.67 \pm 0.01^{\mathrm{a}}$ \\
\hline Ileum & $0.43 \pm 0.02^{\mathrm{b}}$ & $0.45 \pm 0.03^{\mathrm{b}}$ & $0.48 \pm 0.01^{\mathrm{b}}$ & $0.56 \pm 0.02^{\mathrm{a}}$ \\
\hline
\end{tabular}




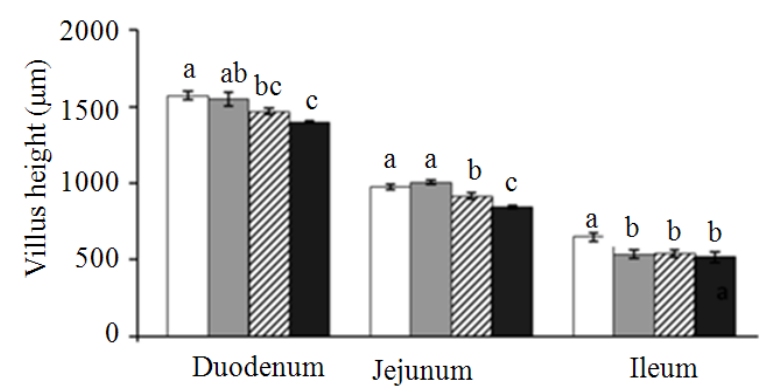

(A)

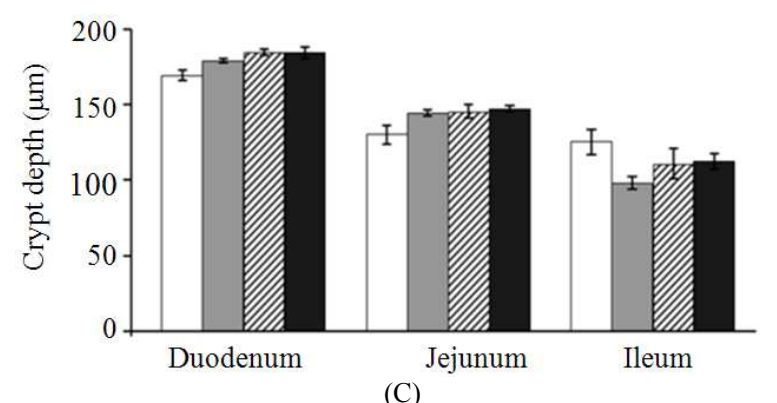

(C)

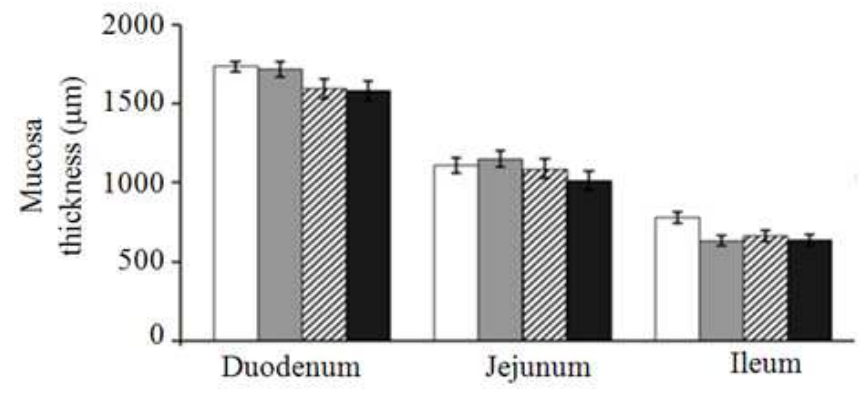

(E)

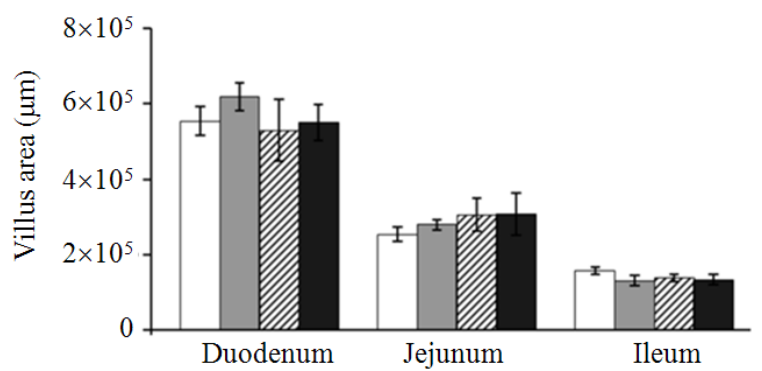

(B)

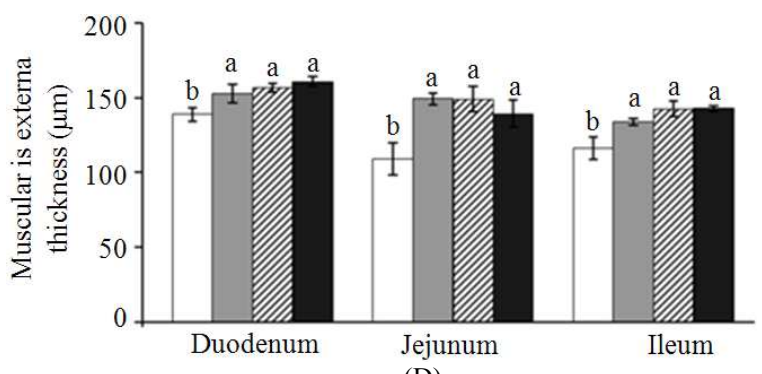

(D)

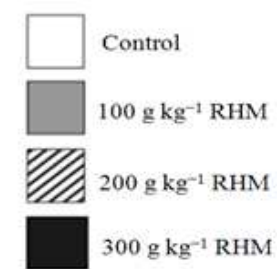

Fig. 1. Villus height (A), villus area (B), crypt depth (C), muscularis externa thickness (D) and mucosa thickness (E) in the duodenum, jejunum and ileum of chickens fed diets containing $0,100,200$ or $300 \mathrm{~g} \mathrm{~kg}^{-1} \mathrm{RHM}$ (mean $\pm \mathrm{SE}$ ). ${ }^{\mathrm{a}-\mathrm{c}}$ Means with no common superscripts are significantly different $(p<0.05)$

Breast weight was significantly lower $(\mathrm{p}<0.05)$ in the 200 and $300 \mathrm{~g} \mathrm{~kg}^{-1}$ RHM groups (11.20 and $10.83 \%$ bird $^{-1}$, respectively) compared with that in birds fed the control diet $\left(12.91 \%\right.$ bird $\left.^{-1}\right)$. There were no considerable differences in the weight of the dressing, wing, thigh plus drumstick, heart, liver or proventriculus $(p>0.05)$. Nevertheless, gizzard weight tended to increase with an increasing level of dietary RHM and was significantly greater $(\mathrm{p}<0.05)$ in the 200 and $300 \mathrm{~g} \mathrm{~kg}^{-1}$ RHM-fed birds $\left(2.58\right.$ and $2.81 \%$ bird $^{-1}$ ) compared with those fed the control $\left(2.09 \%\right.$ bird $\left.^{-1}\right)$ or the $100 \mathrm{~g} \mathrm{~kg}^{-1}$ RHM diet $\left(2.04 \%\right.$ bird $\left.^{-1}\right)$. The digesta $\mathrm{pH}$ of the crop and gizzard of birds fed the diets containing 200 (4.94 and 3.19, respectively) and $300 \mathrm{~g} \mathrm{~kg}^{-1}$ RHM (5.01 and 3.36, respectively) was significantly lower $(\mathrm{p}<0.05)$ than that of the control birds (5.30 and 4.02, respectively) or the chickens fed diets containing $100 \mathrm{~g} \mathrm{~kg}^{-1}$ RHM (5.49 and 4.06 , respectively). However, no difference in the digesta $\mathrm{pH}$ of the contents of the small intestine was observed. Table 4 displays the weight and length of the small intestine of broilers. The intestinal weight and length did not differ $(p>0.05)$ among the experimental groups. Intestinal diameter of duodenum, jejunum and ileum tended to increase with increasing levels of dietary RHM and was significantly greater $(p<0.05)$ in birds in the 300 $\mathrm{g} \mathrm{kg}^{-1}$ RHM group $\left(0.70,0.67\right.$ and $\left.0.56 \mathrm{~mm} 100 \mathrm{~g} \mathrm{BW}^{-1}\right)$ compared with those fed the control diet $(0.60,0.43$ and

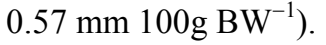



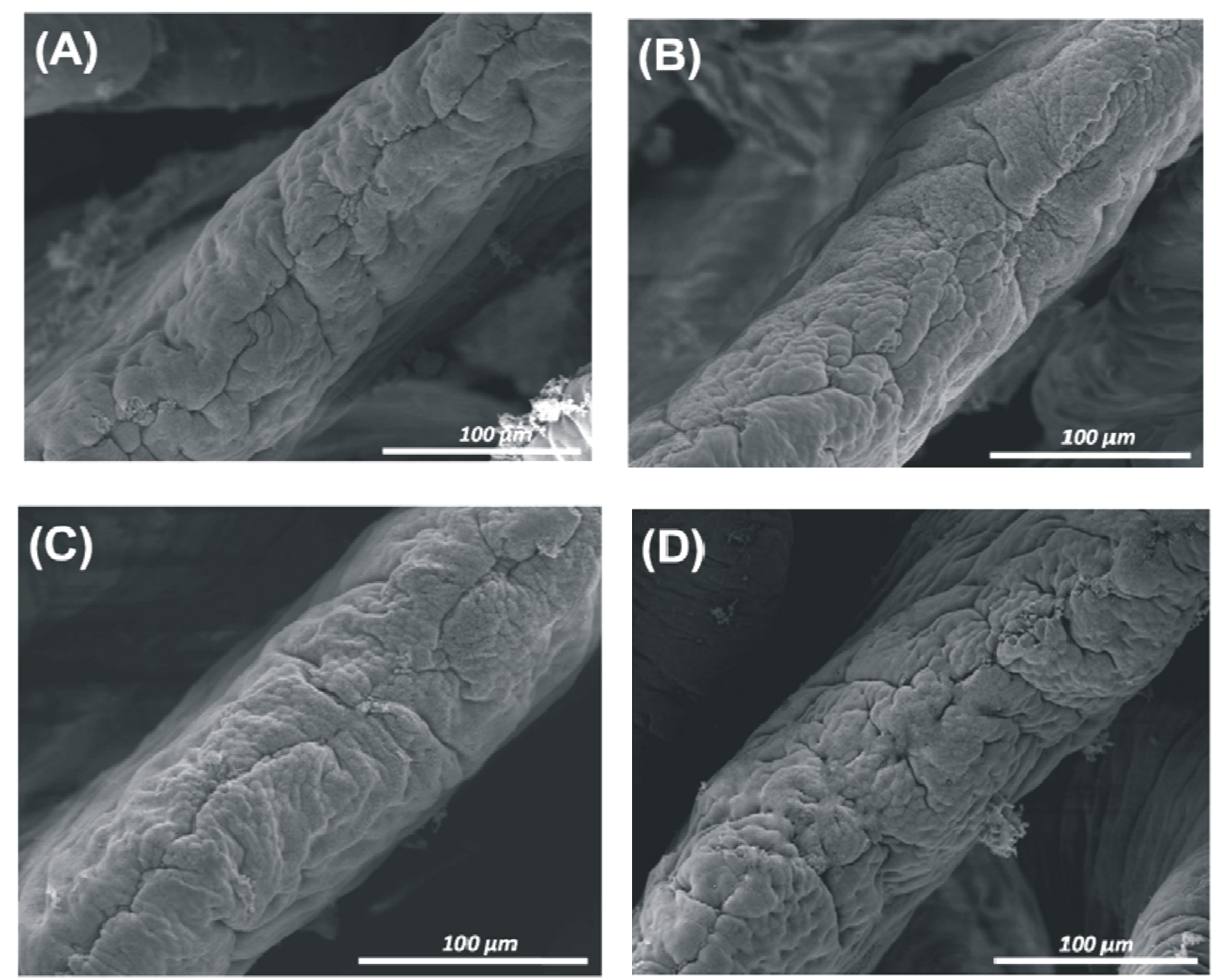

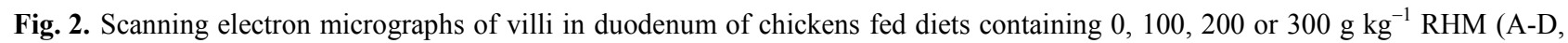
respectively). The tissues had rough surfaces and were composed of cell clusters of aggregated epithelial cells. Scale bar $=$ $100 \mu \mathrm{m}$, magnification: $\times 450$

\subsection{Light Microscopic Assessments}

Villus height, villus area, mucosa thickness, muscularis externa thickness and crypt depth are presented in Fig. 1. Villus height (Fig. 1A) tended to decrease in value in all segment with increasing levels of dietary RHM and significantly declined $(\mathrm{p}<0.05)$ in the 200 and $300 \mathrm{~g} \mathrm{~kg}^{-1}$ groups when compared to the control birds. In terms of the thickness of the muscularis externa, (Fig. 1D) all segments of the dietary RHM-fed birds showed higher values than those of the control birds $(\mathrm{p}<0.05)$. However, no significant differences in villus area (Fig. 1B), crypt depth (Fig. 1C) or mucosa thickness (Fig. 1E) were found $(p>0.05)$ among the treatment groups.

\subsection{Observations of the Epithelium on the Villus Surface}

The surface of the duodenal villi seemed to be similar in terms of histological phenomenon in all treatment groups (Fig. 2A-D). The tissues displayed a rough surface and were composed of cell clusters of aggregated epithelial cells. No morphological changes were found in the villi tip of the jejunum (Fig. 3A-D) and ileum among the treatment groups (Fig. 4A-D). An area of smooth cells covered by a flat epithelium was observed in all experimental groups. Nonetheless, segmented filamentous bacteria (white arrow) were often found on the surface of the ileal villi in the dietary RHM-fed birds (Fig. 4B-D). 
Tossaporn Incharoen / American Journal of Animal and Veterinary Sciences 8 (2): 79-88, 2013
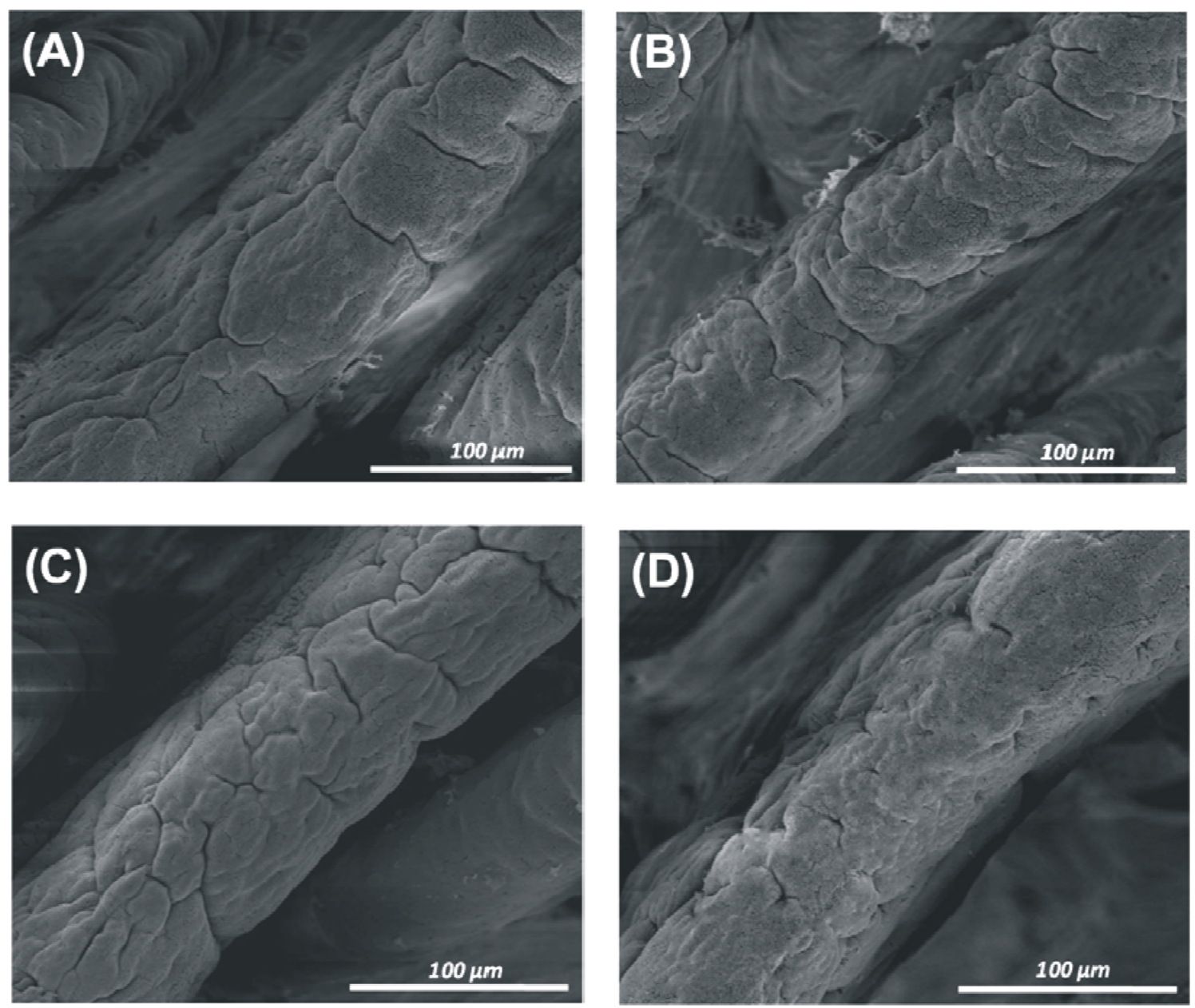

Fig. 3. Scanning electron micrographs of villi in jejunum of chickens fed diets containing $0,100,200$ or $300 \mathrm{~g} \mathrm{~kg}^{-1} \mathrm{RHM}$ (A-D, respectively). An area of smooth cells covered by a flat epithelium was observed. Scale bar $=100 \mu \mathrm{m}$, magnification: $\times 450$
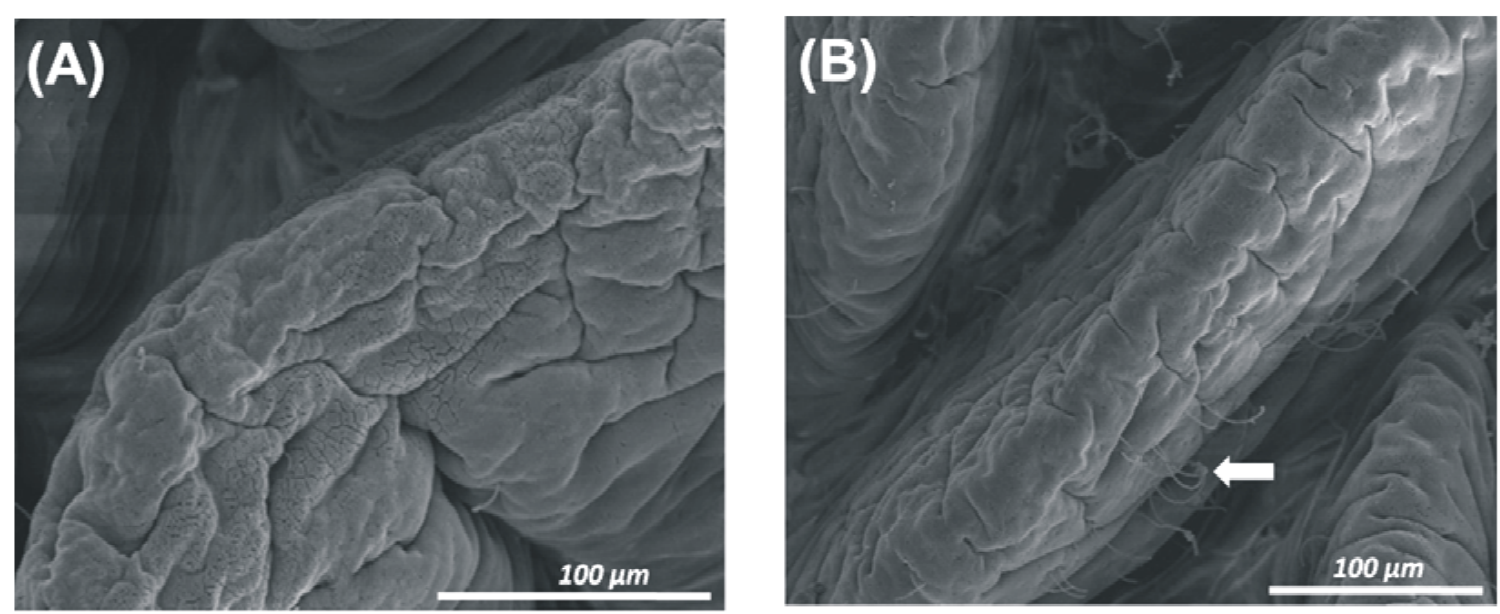

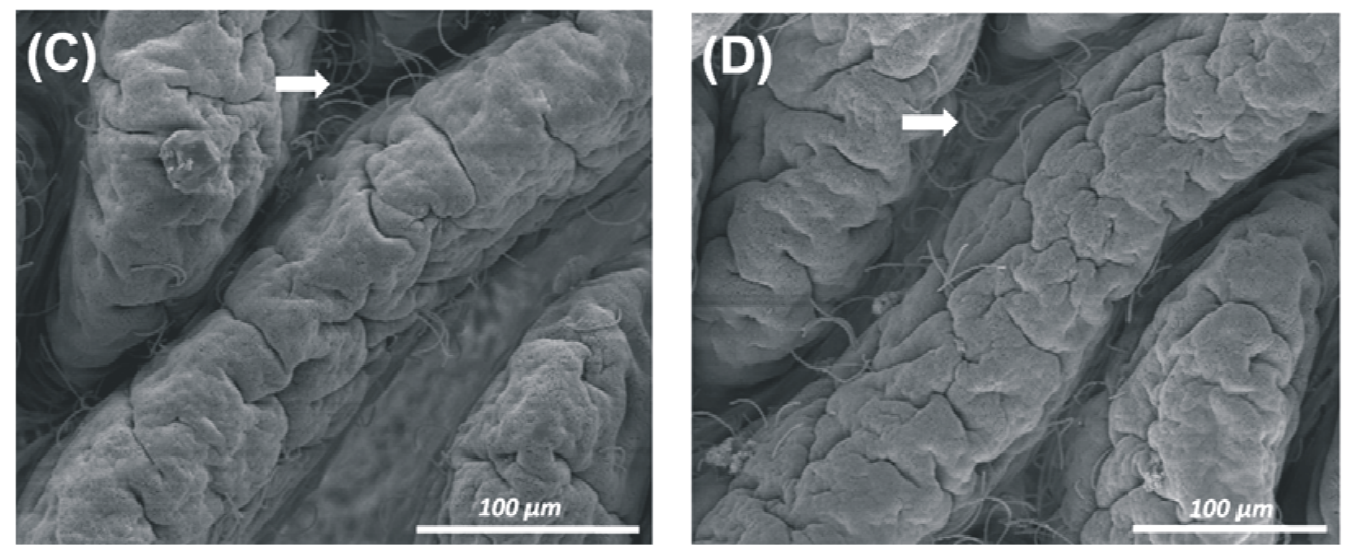

Fig. 4. Scanning electron micrographs of villi in ileum of chickens fed diets containing 0, 100, 200 or $300 \mathrm{~g} \mathrm{~kg}^{-1} \mathrm{RHM}$ (A-D, respectively). Segmented filamentous bacteria were often observed on the surface of the villi in dietary RHM-fed birds. Scale bar $=100 \mu \mathrm{m}$, magnification: $\times 450$

\section{DISCUSSION}

In the current trial, the RHM product consists of mostly cellulose, hemicelluloses and lignin, which is categorized as a source of insoluble fiber. Recent reports have suggested that the optimal inclusion of insoluble fiber in poultry diets can stimulate performance in broiler chickens (Gonzalez-Alvarado et al., 2007; JimenezMoreno et al., 2011), breeder hens (Mohiti-Asli et al., 2012) and turkeys (Sklan et al., 2003). This seems to correlate with other studies, which have stated that insoluble fiber could improve crude fat and starch digestibility (Hetland et al., 2003) and extend nutrient retention (Jimenez-Moreno et al., 2009). In this study, the higher body weight gain and lower FCR in birds fed diets containing $100 \mathrm{~g} \mathrm{~kg}^{-1}$ RHM may be due to improved nutrient utilization of digested feed. Similarly, pullet chicks have a good FCR and the best protein and fat retention when fed $15 \%$ dietary rice hull meal (Adeniji, 2010). The addition of rice hull meal to duck diets enhanced weight gain and FCR compared to the control birds (Wu et al., 2012). These rice hull fed-birds were able to maintain adequate weight gain, presumably because the properties of insoluble fiber increased the physical competency of the gastrointestinal tract. In addition, dietary fiber plays a physiological role in the digestive tract by interacting with gastrointestinal functions, nutrient utilization and enzyme secretion. It is well known that increasing the fiber content of broiler diets increases the size of the gastrointestinal tract (Hetland and Svihus, 2001). Gonzalez-Alvarado et al. (2007) described that inclusion of oat hulls as a source of insoluble fiber in broiler diets increased the gizzard weight and reduced the $\mathrm{pH}$ of gizzard digesta. The current results indicated that birds fed the diets containing 200 and $300 \mathrm{~g} \mathrm{~kg}^{-1}$ RHM had heavier gizzards than birds fed the control diet. This might be associated with the gizzard's need to develop physically to meet the demand for grinding greater quantities of dietary insoluble fiber. High levels of dietary RHM did not affect the carcass characteristics, except the breast weight of birds fed diets containing 200 and $300 \mathrm{~g} \mathrm{~kg}^{-1}$ RHM. Nevertheless, the addition of RHM at 200 and $300 \mathrm{~g} \mathrm{~kg}^{-1}$ in the diets reduced the $\mathrm{pH}$ of the crop and gizzard digesta, suggesting that the reductions in $\mathrm{pH}$ digesta are due to increased Hydrochloric Acid ( $\mathrm{HCl})$ secretion. Low $\mathrm{pH}$ in the digestive tract is correlated with increased mineral salt solubility, which may promote pepsin activity and improve the digestion and absorption of minerals in the upper part of the gastrointestinal tract (Guinotte et al., 1995).

The present histological results demonstrate that the inclusion of RHM in the diet directly affected some structural parameters of the chickens' small intestines. Gross anatomically, no effects of RHM on intestinal weight and length were observed. However, an increase in intestinal diameter was found in chickens fed dietary RHM. The thickness of the muscularis externa also showed higher values in RHM-fed birds than in the control birds. Traditionally, it has been well known that diets including insoluble fiber from the hulls of various cereals have been considered diluted, with negative implications, such as decreased nutrient density of the feed. These findings might result in a physiological compensatory mechanism to increase the absorptive 
capacity in an attempt to assimilate the nutrients from a diet diluted with RHM. Histologically, villus height and mucosa thickness may be used as a good index for understanding the intestinal states that are directly linked to the absorptive function. In this trial, the villus height of all intestinal segments was shorter when the dietary RHM level was increased over $100 \mathrm{~g} \mathrm{~kg}^{-1}$. However, Sarikhan et al. (2010) noted that the villus form of broiler chickens was more developed when the birds were fed a dietary insoluble fiber diet $(0.75 \%)$, inducing a rapid growth rate. This may indicate that extremely high levels of dietary RHM reduces villus formation, resulting in a decreased absorptive area.

The epithelial cells on the villus surface are capable of rapid and extensive morphological and functional adaptation in response to the altered chemical composition of the feed, such as the inclusion of dietary fiber. These cells are derived from mitotic cells situated in the crypt base, which seem to induce many stages of cell histologies on the villus tip surface, depending on the intestinal function. In the current observations, no morphological differences in the epithelial cells were found on the villus apical surface of all intestinal segments among the treatment groups. This phenomenon implies that epithelial cells did not reduce their cell cycles or morphological properties in the presence of dietary RHM, resulting in normal functional competences. Nevertheless, Segmented Flamentous Bacteria (SFB) were observed on the surface of the ileal epithelial cells in dietary RHM-fed birds. SFB are indigenous, non-pathogenic bacteria that are able to colonize the distal part of the small intestine by attaching to the intestinal epithelium and Peyer's patches (Snel et al., 1996). They occur in the intestines of many animal species, including chickens (Incharoen et al., 2010). These bacteria strongly stimulate the host immune response system, such as the induction of secretory $\operatorname{IgA}$ production and regulation of T-cell maturation (Jonsson, 2013). Although the SFB were attached to the ileal epithelia in the dietary RHM-fed birds, this phenomenon cannot be reasonably explained. However, these observations could be related to the properties of the dietary insoluble fiber in RHM. Further study should be carried out to investigate the effects RHM on these SFB.

\section{CONCLUSION}

The present findings suggest that RHM can be used as a source of insoluble fiber in broiler diets at the level of $100 \mathrm{~g} \mathrm{~kg}^{-1}$ to improve growth performance without any adverse effects on carcass, gastrointestinal tract development and histological variables of intestinal villi or epithelial cells.

\section{ACKNOWLEDGMENTS}

The researchers would to like to thank Assoc. Prof. Dr. Wandee Tartrakoon and Ms. Kunlayaphat Wuthijaree for their support and cooperation. I gratefully thank $\mathrm{Mr}$. Sarawut Treetan and Mr. Sarawoot Nakhon for their help in the feeding experiment. Thanks are also extended to members of animal science laboratory who gave their valuable time to help in the conduct of the research.

\section{REFERENCES}

Adeniji, A.A., 2010. Effects of dietary grit inclusion on the utilization of rice husk by pullet chicks. Tropical Subtropical Agroecosyst., 12: 175-180.

Gonzalez-Alvarado, J.M., E. Jimenez-Moreno, R. Lazaro and G.G. Mateos, 2007. Effect of type of cereal, heat processing of the cereal and inclusion of fiber in the diet on productive performance and digestive traits of broilers. Poultry Sci., 86: 17051715.

Guinotte, F., J. Gautron, Y. Nys and A. Soumarmon, 1995. Calcium solubilization and retention in the gastrointestinal tract in chicks (Gallus domesticus) as a function of gastric acid secretion inhibition and of calcium carbonate particle size. Br. J. Nutr., 73: 125-139. DOI: 10.1079/BJN19950014

Hetland, H. and B. Svihus, 2001. Effect of oat hulls on performance, gut capacity and feed passage time in broiler chickens. Br. Poultry Sci., 42: 354-361. DOI: 10.1080/00071660120055331

Hetland, H. and B. Svihus, 2007. Inclusion of dust bathing materials affects nutrient digestion and gut physiology of layers. J. Applied Poultry Res., 16: 22-26.

Hetland, H., B. Svihus and A. Krogdahl, 2003. Effects of oat hulls and wood shavings on digestion in broilers and layers fed diets based on whole or ground wheat. Br. Poultry Sci., 44: 275-282. DOI: 10.1080/0007166031000124595

Incharoen, T., K. Yamauchi and N. Thongwittaya, 2010. Intestinal villus histological alterations in broilers fed dietary dried fermented ginger. J. Anim. Physiol. Anim. Nutr., 94: e130-e137. DOI: 10.1111/j.14390396.2010.00994.x 
Jimenez-Moreno, E., J.M. González-Alvarado, R. Lázaro and G.G. Mateos, 2009. Effects of type of cereal, heat processing of the cereal and fiber inclusion in the diet on gizzard $\mathrm{pH}$ and nutrient utilization in broilers at different ages. Poultry Sci., 88: 19251933. DOI: $10.3382 /$ ps.2009-00193

Jimenez-Moreno, E., S. Chamorro, M. Frikha, H. M. Safaa and R. Lázaro et al., 2011. Effects of increasing levels of pea hulls in the diet on productive performance, development of the gastrointestinal tract and nutrient retention of broilers from one to eighteen days of age. Anim. Feed Sci. Technol., 168: 100-112. DOI: 10.1016/j.anifeedsci.2011.03.013

Jonsson, H., 2013. Segmented filamentous bacteria in human ileostomy samples after high-fiber intake. FEMS Microbiol. Lett., 342: 24-29. DOI: 10.1111/1574-6968.12103

Miles, R.D., G.D. Butcher, P.R. Henry and R.C. Littell, 2006. Effect of antibiotic growth promoters on broiler performance, intestinal growth parameters and quantitative morphology. Poultry Sci., 85: 476-485.

Mohiti-Asli, M., M. Shivazad, M. Zaghari, M. Rezaian and S. Aminzadeh et al., 2012. Effects of feeding regimen, fiber inclusion and crude protein content of the diet on performance and egg quality and hatchability of eggs of broiler breeder hens. Poultry Sci., 91: 3097-3106. DOI: 10.3382/ps.2012-02282
Sarikhan, M., H.A. Shahryar, B. Gholizadeh, M.H. Hosseinzadeh and B. Beheshti et al., 2010. Effects of insoluble fiber on growth performance, carcass traits and ileum morphological parameters on broiler chick males. Int. J. Agric. Biol., 12: 531-536.

Sklan, D., A. Smirnov and I. Plavnik, 2003. The effect of dietary fibre on the small intestines and apparent digestion in the turkey. Br. Poultry Sci., 44: 735740. DOI: 10.1080/00071660310001643750

Snel, J., M.E. van den Brink, M.H. Bakker, F.G.J. Poelma and P.J. Heidt, 1996. The influence of indigenous segmented filamentous bacteria on small intestinal transit in mice. Microbial. Ecol. Health Dis., 9: 207-214.

Svihus, B., 2011. The gizzard: function, influence of diet structure and effects on nutrient availability. World's Poultry Sci. J., 67: 207-224. DOI: 10.1017/S0043933911000249

Wu, L., X. Guo and Y. Fang, 2012. Effect of diet dilution ratio at early age on growth performance, carcass characteristics and hepatic lipogenesis of Pekin ducks. Brazilian J. Poultry Sci., 14: 43-49. DOI: 10.1590/S1516-635X2012000100008 